\title{
ANALYSIS OF THE RESTRUCTURING PROCESS OF THE HOUSING STOCK OF RĂDĂUȚI MUNICIPALITY BETWEEN 1990-2019
}

DOI: https://doi.org/10.18509/GBP210305l

UDC: 640.1:311.2(498)"1990/2019"

316.334.56(498)

\section{Luminița-Mirela Lăzărescu \\ Vasile Efros \\ Daniela Liliana Diacon}

„Stefan cel Mare” University of Suceava, The Faculty of History-Geography, Department of Geography, Romania

\begin{abstract}
This article aims to characterize the current situation of the housing stock on the territory of Rădăuți municipality as a result of the changes that occurred between 1990 and 2019 in its structure and characteristics and to synthesize a series of territorial disparities. The research aimed to highlight the general dynamics of the housing stock and capture the territorial changes that reflect the process of restructuring and regeneration that the city's housing stock has gone through in the last three decades.

To achieve the purpose of the study, in analyzing the dynamics of the housing fund in Radauti, the following indicators were taken into account: number and type of existing housing, number of existing housing by the form of ownership and source of financing, the annual number of completed housing, housing, age of housing. The territorial analysis aimed to highlight the expansion of the built fund (especially in residential areas), highlight the distribution of housing in the city, identify structural changes in urban space as a result of the urban restructuring process that began after 1990.

Highlighting the most significant quantitative and qualitative changes determined by the dynamics of the housing stock was based on the analysis, interpretation, and processing of bibliographic, cartographic, and statistical data. The graphic and cartographic representations obtained were the starting point for the subsequent analyzes and interpretations that allowed the characterization of the dynamics of the housing stock as well as the formulation of the study conclusions.

The research results show that although most of the housing stock in Radauti was built before 1990, the restructuring process is current and is achieved both by densifying the built space and by a peripheral expansion of residential areas. The trends that can be underlined in the evolution of the housing stock of Rădăuţi municipality are the increase of the share of individual dwellings in the overall housing fund, the formation of new residential neighborhoods dominated by individual dwellings, as a result of the construction of the collective housing on the vacant spaces inside, the renewal of the existing housing stock, the emergence of problems related to access to urban utilities.
\end{abstract}

Keywords: housing stock, dwelling, dynamics, residential areas, urban restructuring

\section{INTRODUCTION}

Housing is an essential component of human life that takes place within the human habitat, being supported by a specific infrastructure (housing, utilities, landscaping outside the home, different services). Housing can be defined in various ways. At its most 
basic level, housing is defined by the characteristics of the physical structure and the costs and construction of that housing. At a deeper level, housing "determines the mutual relationship between every single human being and surrounding physical and social space. " [1]

The structure of the housing stock in each country reflects a bit of its history and political choices [2], its dynamics are closely linked to the socio-economic context, and its restructuring takes place, in particular, to change the political regime. While the establishment of the communist regime contributed, in most Eastern European states, to the renewal and resizing of the housing stock, by building a large number of homes, its fall imposed a succession of economic changes that led to the disorganization of this sector of economic activity.

After 1990, Romania experienced a decade of economic instability and decline, the difficulties of economic recovery being related to the lack of structural reforms, the existence of an outdated infrastructure [3], and, especially, the resistance to change and anchoring in old communist practices. The relaunch of the activity of the housing construction sector, in each ex-socialist country, was related to the ability of states to overcome the transition period and to adapt as quickly and efficiently as possible to the requirements of the market economy. The experience of the 30 years since the fall of the regime in Romania, has shown us that, in general, state intervention in housing management has decreased progressively and the involvement of the population in the construction and maintenance of their homes has increased. Even if the principles of organizing urban space according to capitalist rules were adopted earlier, the pace of change in the built environment and residential differentiation occurred much later [4].

The most important general trends in the transition cities are the return of the importance of land rent and an increasing number of actors competing for space, renaissance of selfgovernment, the increase of social and spatial differentiation, the transformation of employment structure, reshaping of townscape, and the physical transformation of the urban space [5].

After 1990, there were changes in the mechanisms regarding the construction and distribution of housing that led to changes in the structure of the housing stock and the characteristics of residential areas of Romanian villages and towns: mobility restrictions to large cities were removed, it was regulated the property right, the citizens acquired the freedom to build houses on their own, to choose the desired place of residence, the provisions restricting the construction of houses on the outskirts of the settlement were eliminated [6]. Contradictions between the inherited socialist urban patterns and newly established capitalist rules created tensions resulting in the restructuring of existing urban areas and the formation of new postsocialist urban landscapes [7].

Decentralization of state power, increasing the decision-making role of regional and local administrations, disorganizing the activity of the construction sector, reducing state involvement in financing housing construction and maintenance, the sale of state-owned housing to the population, lack of a regulated market for sale-purchase or rental of housing, these were just some of the changes that severely affected, in Romania, the dynamics of the housing stock in the first decade after the fall of communism. This period was marked, in all cities of the country, by the slowdown, even stagnation, of the pace of housing construction, most cities experienced, at different intensities, the housing crisis. The transition to a market economy has been slow, and the recovery of the housing construction sector has experienced different rhythms from one county to another, from 
one locality to another, depending on the capacity and availability of local authorities to identify housing problems and use the available financial resources to solve them.

The issue of ensuring adequate living conditions and the renewal of the housing stock is a topical concern in Romania, given that European statistics indicate that Romania ranks last in the EU in most indicators of housing reviewed. Romania is, after Bulgaria, the poorest country in the EU, but has the worst living conditions. The housing stock faces many problems in all localities of the country: the real estate market is deteriorating rapidly, public housing is insufficient (they hold less than $2 \%$ of the housing stock), the housing rental market is unofficial and unregulated, cities are experiencing uncontrolled expansion and with population losses, housing is among the most expensive, housing is overcrowded, at the same time there is the highest number of unoccupied housing, housing precarity has the highest value among EU countries [8]. Housing equipment is a major problem, especially in poor rural areas, where utility is difficult to provide. Informal or unhealthy living is still a relatively localized problem, but with obvious growth trends [9].

In this context, the analysis of housing problems is timely and relevant for any locality in Romania. The analysis of the process of restructuring the housing stock of small and medium-sized cities provides important information to all decision-makers in the community interested in the development of the local community (local authorities, planners, builders, architects, citizens). The diagnosis of the existing situation and the description of the factors that influenced the development and the renewal process of the housing fund represent the starting point for the elaboration of local development policies and the necessary steps for better landscaping for housing, according to locally identified needs. The research of the dynamics of the housing fund between 1990 and 2019 aims at the analysis of the changes produced in the structure of the housing fund of Rădăuți municipality. The approach to the change process focused in particular on the analysis of quantitative changes that are highlighted by statistical data. The territorial analysis focused on identifying the areas of extension of residential spaces and changes in urban areas. The study has a theoretical value, contributing to the enrichment of knowledge related to this topic, because, until now, this topic has not been addressed in the research conducted on the municipality of Radauti.

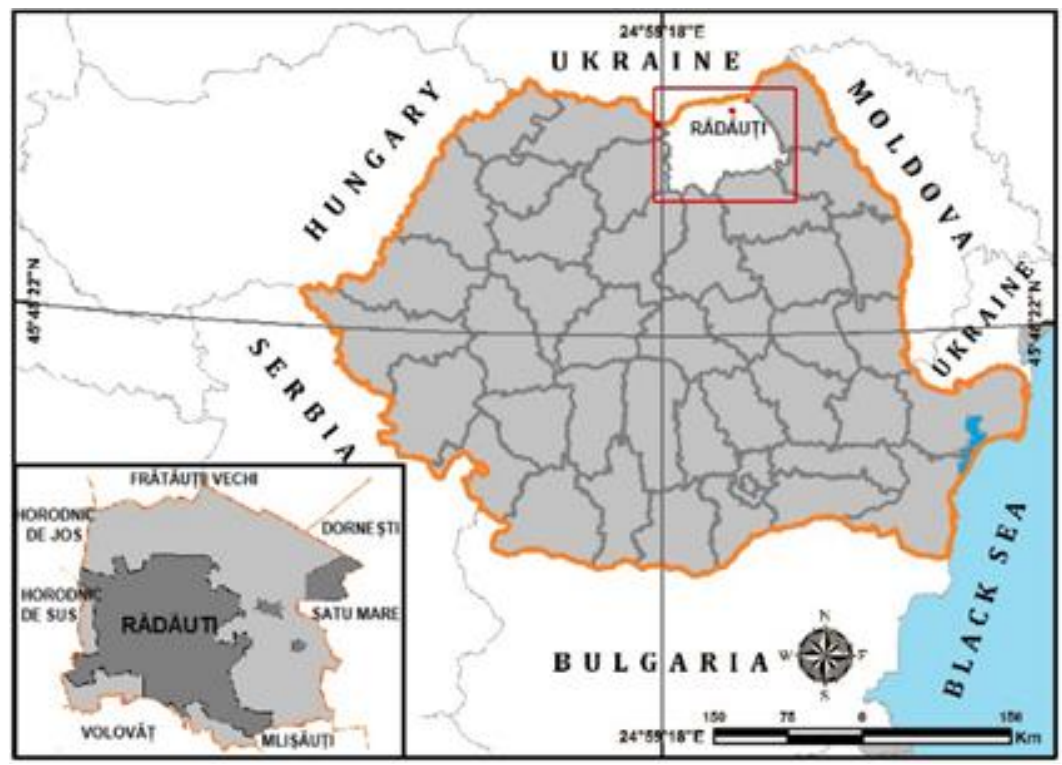

Figure 1. Location of the study area. 
The municipality of Rădăuți is located in the northeast part of Romania and the northwest part of the Moldavian Plateau. It is located in the northern part of Suceava County, on the right bank of the Suceava River, in the depression of the same name in the Suceava Plateau.

The town is territorially delimited as follows: in the north - FrătăuțiiVechi commune; in the northeast - Dornești commune; in the east - Satu-Mare commune; in the south Bădeuți communes and Volovăț; in the west - Horodnic commune, is located at an altitude between $260 \mathrm{~m}$ and $380 \mathrm{~m}$, the mathematical position of the city being defined by the coordinates of 25035 east longitude and 47051 northern latitudes.

The total area of Rădăuți municipality is 3,230 ha. As for the surface urban development in 2018, it was 1,360 ha, which represents $40.96 \%$ of the total area of the city. Within Suceava county, Rădăuți municipality is in second place after area and in third place in terms of population.

\section{METHODOLOGY}

The study was structured in two parts: the first part proposes the identification and description of some factors that influenced, as a whole, the development of the housing stock and its restructuring before and after 1990, the second illustrates the changes in the housing fund structure in the post-communist period by analyzing the main indicators the housing stock. The description of the framework in which it evolved, after 1990, Rădăuți municipality took into account the review of some aspects of political-administrative, demographic, economic nature that influenced, directly or indirectly, housing and the structure of the housing fund. Obtaining useful information for drawing this framework involved: consulting specialized studies, spatial planning strategies and economic development of the city; selection of relevant statistical data from the Tempo ONLINE database of the National Institute of Statistics; an information processing approach focused on interpretation and deduction, completed with methods of statisticalmathematical analysis and graphical representation of data using Microsoft Excel.

The analysis of the housing stock dynamics was based on the mathematical-computer processing of statistical data corresponding to the following indicators: total number of existing homes, number of homes completed during the year (by area of residence; forms of ownership, sources of financing); the existing living space related to the dwellings completed during the year and on the interpretation of the results. The statistical data for the mentioned indicators were taken from the Tempo ONLINE database of the National Institute of Statistics. The values of some derived indicators were calculated based on the data associated with the main indicators of the housing stock.

Highlighting the territorial dynamics of the built space and some characteristics of residential spaces was achieved by using the ArcGIS program. Existing data in the ANCPI database for the years 1900 and 2019 and data collected from the field were used.

\section{RESULTS AND DISCUSSIONS}

\section{The premises for the development and restructuring of the housing stock of the municipality of Rădăuți}

Housing is a process associated with human existence and, at the same time, a tool for socio-economic development that involves significant financial and material flows. Housing ensures both the well-being of the population (because it responds to an essential human need) and the development of the settlement as housing construction, provision of 
services and utilities necessary for housing are activities integrated into the economic circuit that manages considerable financial flows that are oriented to both populations (income) and the community (as taxes).

The housing fund is defined as the totality of the existing housing units in a territory, regardless of the type of property: residential houses, specialized houses (homes for the elderly), apartments, service rooms, and other housing units in other buildings useful for housing. The elementary unit of the dwelling fund is the individual dwelling.

The dwelling (apartment) is the built unit consisting of one or more living rooms located at the same level of the building or different levels, provided, in general, with outbuildings (kitchen, bathroom, etc.) or with other service spaces, independent from a functional point of view, having a separate entrance from the staircase house, courtyard or street and which has been built, transformed or arranged to be used, in principle, by a single household [10].

The dynamics of the housing stock of Rădăuți municipality have been strongly influenced, over time, by historical, demographic, political, and economic factors.

Historical factors had a major influence on the formation and structuring of the housing stock in Radauti, they coincide with the main events in the history of the settlement, each stage of territorial and functional evolution through contributing to the structuring of urban space and, implicitly, to the creation and development housing stock.

The current characteristics of the housing stock in Rădăuți municipality were acquired during its historical evolution and reflect the different political and socio-economic contexts in which it was built. The establishment of the housing fund in Rădăuți is a process that began with the shaping of the initial nucleus of the settlement, more than 600 years ago, and which has continued until today, as a way of satisfying a fundamental human need. Given the age of the city, only the buildings and houses built in the last three stages of evolution have been preserved in the current structure of the built fund: from the period of the Habsburg occupation (late eighteenth century - early twentieth century), from the years of the socialist regime in the middle of the twentieth century until 1989) and the post-communist period (after 1990 - until now).

After 1920, Rădăuți underwent an important stage of restructuring and reconstruction to restore the built heritage destroyed during the First World War. In the first half of the twentieth century, the territorial expansion of the locality was favored by the agrarian reform of 1922. The agricultural land between Liceului Street (later „V. I. Lenin Street, now Calea Bucovinei) and Volovățului Street was divided into construction lots and distributed to the population [11], in a few years many individual houses were built here, the neighborhood still being preserved in the internal structure of the city.

The socialist period was marked by significant population growth (the population of the settlement increased from 18,780 inhabitants in 1965 to 23,580 at the end of 1980) [12] as a result of positive natural and migratory dynamics (favored by the adoption of a natalist policy in 1965 and the process of industrialization of the town). The need to provide housing for the newly established workforce in the city determined increasing the volume of investments to expand living space and resulted in the configuration of the new city. This area occupies the southern and southwestern part of the locality, it has kept a physiognomy specific to the socialist period and presents a systematized structure predominantly rectangular with straight streets that intersect at right angles and enclose inside geometric spaces occupied by collective housing complexes: Bogdan Vodă, Călărași, Stadion and Hurmuzachi neighborhoods (built between 1965 and 1970); Hipodrom - Grănicer, Mihai Viteazul and Obor neighborhoods (1975 - 1980). After 1990, 
the transition to a market economy led to the decentralization of spatial planning actions, removing the old rules and restrictions of systematization. Decentralization of the economy and administrative decisions have contributed to increasing the role of local government and the community in setting priorities, its own rules of development, and urban expansion. Until the year 2000, the restructuring of the housing fund of Rădăuți was carried out on a small scale, at the initiative of the owners, focused on the qualitative dimension and materialized through actions of the redevelopment of existing homes to modernize, repair, maintain them according to identified needs, ensure efficiency (changing windows, roofs, insulated buildings) and increasing their comfort by connecting to various utilities. Subsequently, under the influence of the revitalization of the national and local economy and housing models specific to Western Europe, the preference for individual housing became evident, the city experiencing a new stage of territorial expansion by capitalizing on vacant urban and agricultural land on the outskirts of residential buildings. At this stage, in addition to the involvement of the population, there was an increase in the number of specialized economic agents that entered the real estate market. They initially turned their attention to the existing undeveloped lots (in town and on the outskirts) and, later, to the old buildings, to obtain well-located land after their demolition. The restructuring of the housing stock in Rădăuți was the result of the process of capitalization of different categories of land for residential uses and was achieved by densification of the interior space; replacing old buildings with new, modern ones, and arranging new residential neighborhoods on the outskirts of the city (southwest, north, west, southeast).

In Rădăuți, the formation of residential areas began with the shaping of the initial nucleus of the settlement, in the 14th century, in the northern part of the settlement and has continued until today. The territorial extension of the settlement was achieved, predominantly to the south compared to the initial settlement and some extent to the eastwest. Each stage of development of the settlement materialized in a new stage of territorial expansion, achieved by the appearance of new living spaces, located, usually to the south of the existing ones.

Demographic factors play a key role in measuring the demand for housing and, in part, in meeting the need for existing housing at the local level by building, buying, or renting housing. Population and efforts to ensure adequate living conditions play a key role in ensuring the quality of housing in a human settlement, as the quality of housing is a key element of a person's quality of life [13].

The demand for housing in the Rădăuți municipality has always been correlated with the dynamics registered by the number of inhabitants. The periods in which there were significant increases in the number of inhabitants (either as a result of a positive natural balance or as a result of the establishment of a larger number of migrants in the locality) determined a corresponding development of the housing fund.

The number of population and the structure by age groups contribute to the configuration of housing demand (housing is a basic need of the population) and to the sizing of quantitative and qualitative indicators of housing (degree of insurance of the population with housing; the average number of people/housing; the degree of agglomeration of the dwelling, etc.). The desire for the comfort of the population (expressed by the preference for certain characteristics of housing, neighboring space, and access to urban utilities and services) directs individual efforts, those of authorities and businesses to find the most appropriate solutions to increase the quality of construction, expand technical networks. and the diversification of services associated with the housing sector. 
From the point of view of the population-housing ratio, the year 1990, which marked the transition from the planned demographic model to the western one (of the free decision in the sizing of the family) cannot be considered an absolute limit. The transition to the current demographic model has taken place gradually, a series of events occurring before 1989 have influenced the demand for housing after a few decades. The evolution of the population in Rădăuți was fluctuating, registering successive increases and decreases, depending on the values of the demographic indicators associated with the natural and territorial dynamics of the population. From the formation of the settlement until 1990, the population dynamics and the development of the local economy were two important factors that influenced the formation and expansion of residential areas. We mention this: the period 1774-1870, which was distinguished by a large number of arrivals (Germans and Jews) as a result of the policy of colonization carried out by the Austrian rule; period 1965-1989, which was characterized by a sharp increase in the number of population (from 18,780 inhabitants in 1965 to 30,454 at the end of 1989 , according to the data provided by the National Institute of Statistics of Romania).

After 1990, the adoption of an indifferent demographic policy, the political instability, the decline of industry and mass redundancies, the financial difficulties, the lack of measures to protect the population were reflected in an obvious demographic decline caused by the dramatic decline in birth rates and increasing emigration. In the socioeconomic context of the Romanian post-communist society, the opening of borders represented, for many citizens, an opportunity to find, outside the country, better-paid jobs, a decent living, and the possibility of saving for the construction of their own homes. Abroad, they came into contact with housing models in the Western Area, which contributed greatly to changing their housing preferences. The desire for comfort, space, intimacy associated with the financial power acquired during the years of work abroad, materialized in the desire to build individual homes, which imposed an upward trend in housing construction in Radauti (stronger since 2006) and determined in new stages of territorial expansion of the city. In conclusion, we appreciate that in the analyzed period the numerical evolution of the population was in an ascending trend, the number of the population increasing by 3,667 people (from 31,607 inhabitants in 1992 to 35,260 in 2020). To assess the degree of housing insurance of the existing population, we compared the average annual growth rate of the population with the average annual growth rate of the number of dwellings, an aspect highlighted in Figure 2.

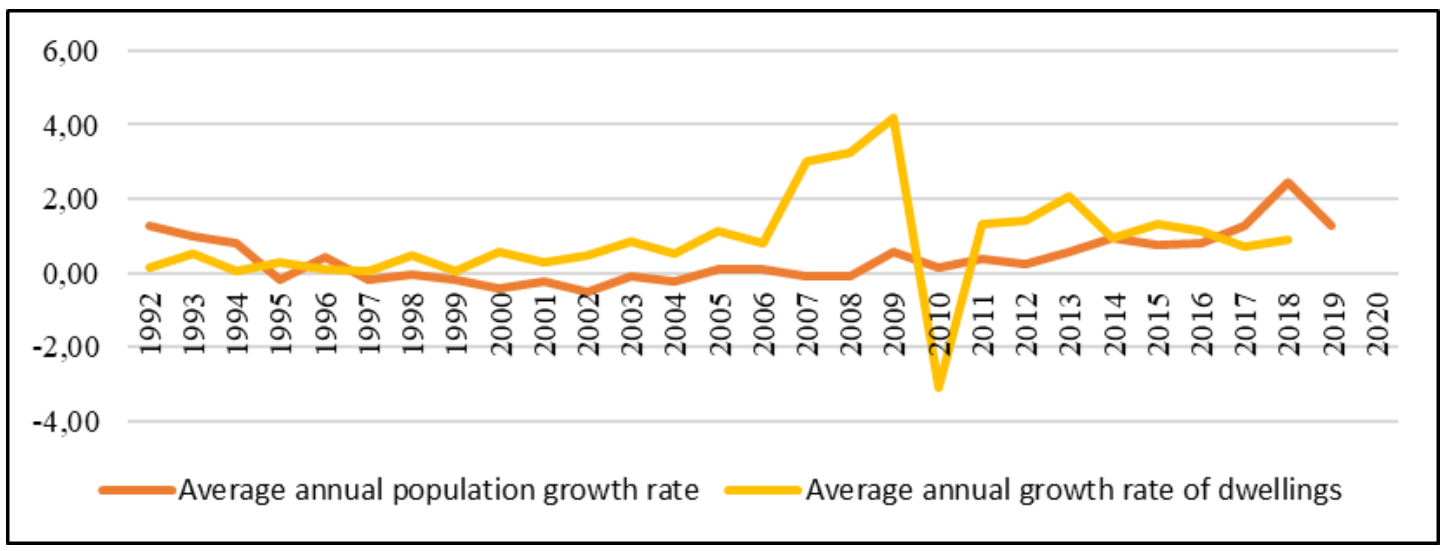

Figure 2 The evolution of the average annual growth rate of the population and the number of dwellings, in the municipality of Rădăuți, between 1992 and 2019

(Source: authors' processing of INSSE TEMPO statistics: POP107D, LOC101B) 
We notice that in the municipality of Rădăuți, during the analyzed period, the average annual growth rate of the number of dwellings was higher than the increase of the population number, a positive aspect from the perspective of satisfying the demand for housing within the municipality of Rădăuți. Between 2006 and 2009, the growth rate of the number of homes built marked a significant increase from $0.81 \%$ to $4.18 \%$, as a consequence of the growing demand for new homes, especially in separate individual buildings. The satisfaction of these preferences was financially supported by emigrants by sending large sums of money to the country, but also by increasing the number of private investors in the field of residential construction.

The changes produced, in the three decades of transition to the market economy, in the structure by age groups of the population have played a decisive role in sizing the demand for housing and satisfying it. During the studied time interval, the evolution by age groups of the population of Rădăuți followed, in general, the specific trend of the European space and was in the model characteristic of the ex-communist states (decreasing the share of the young group, increasing the share of the population years and the manifestation, more and more significant, of the demographic decline).

From the perspective of assessing the influence of demographic restructuring on the configuration of housing needs, another aspect to consider is the population dynamics by intermediate age groups, given that the demand for housing is different in age groups: is higher in the 20-30 age groups (young people starting a new household and separating from their families) and in the 30-40 age groups (increasing household size and new housing preferences) and is weaker in the level of the young group, aged between 0 and 15 years (children live with their parents) and the old group, over 60 years (most of the population already benefits from housing at this age). In this respect, the analysis focused on the comparison between the average annual growth rate of the number of the population (as a whole and for age groups between 20-30 and 30-40) with that of the average annual growth rate of the number of dwellings in the municipality Radauti for the period 1992-2018, elements highlighted in Figure 3.

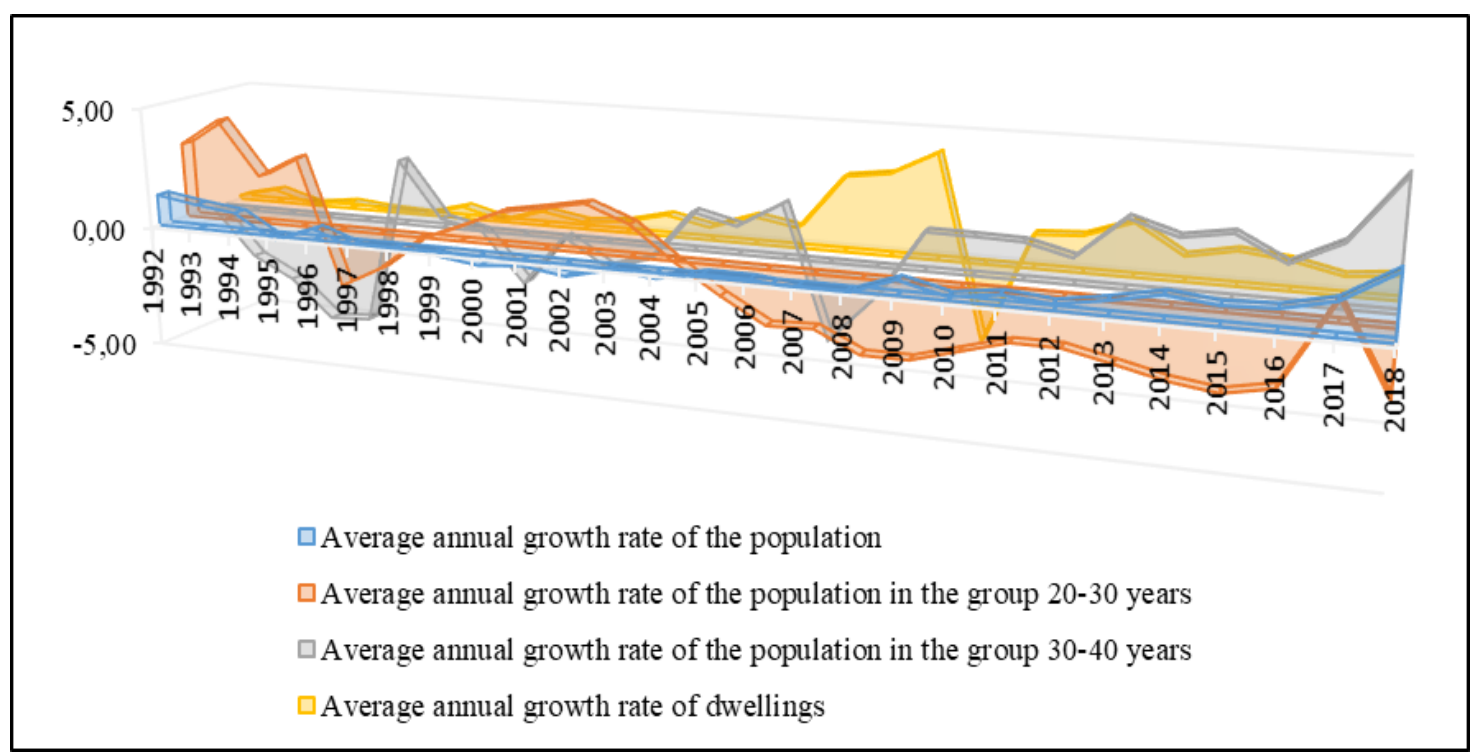

Figure 3. The average annual growth rate of the population, total and for the age groups

20-30 years and 30-40 years and the average annual growth rate of the number of dwellings in the Rădăuți municipality, between 1992 and 2018

(Source: authors' processing of INSSE TEMPO statistics - POP107D, LOC101B) 
For the period 1992-2006, we observe that the intervals with a more pronounced growth rate of the population in the 20-30 and 30-40 age groups are not doubled nor followed by an acceleration of the average annual growth rate of the dwelling number, which indicates the existence of a strong housing crisis, in Radauti, at that time. In the period 2006-2011, although the average annual growth rate of housing exceeded the growth rate of the population aged 30-40, meeting the demand for housing for young people remained an unresolved issue in Radauti.

Structural change in local, regional, and national economies is a consequence of political change and puts pressure on urban development. These pressures interact with the changing nature of urban governance, the economic and political conditions in which the development of a city takes place, shape the process of restructuring the housing stock, the provision, and management of housing [14].

The development and diversification of economic activities took place throughout the historical evolution of Radauti, but they manifested themselves more strongly, with visible results in the structuring of the territory, starting from the 19th century, under the Habsburg occupation, continuing in the socialist and post-socialist period.

During the Habsburg occupation, the local economy developed significantly compared to the previous period. The Austrian authorities offered various facilities to immigrants to settle in the locality and undertook landscaping work which allowed the expansion of the land intended for housing construction, which stimulated the growth of the population and, consequently, the development of the housing fund. Since the end of the 18th century, the settlement enters an urban development phase, in 1819 it is raised to the rank of a fair, the built space of the city expands, the commercial-craft nucleus is formed (currently the historical center of the city ) [15]. In addition to the administrative and commercial-craft function, the center of the settlement acquired, in the nineteenth century, a residential function, the floor of the buildings was used as housing, while the ground floor was intended for business. The housing function of the central area was significantly emphasized during the socialist period. The restructuring of the historic center under the vision of the socialist party began with the transformation of the spaces on the ground floor of the buildings into commercial spaces and continued the construction of the civic center. The modernization and systematization of the central part concerned especially the northern half of the historic center, where the old structures were removed and replaced with new buildings and blocks of flats whose physiognomy and functionality was adequate to the political and administrative principles promoted during that period. The floors of the buildings in the central area, once inhabited, were distributed on social criteria, to needy families, especially those of Roma ethnicity, other spaces being used as locations for state institutions.

The transition from the centralized economy, specific to the communist regime, to the market economy imposed the restructuring of economic activities. In the context of the restructuring of the industry, the large enterprises built-in Rădăuți during the socialist period, lacking resources and market, gradually diminished their activity and laid off, in stages, their employees. Some of the dismissed workers, settled in the city from neighboring rural areas, returned to their properties, others emigrated because, in the first years after the fall of socialism, the city experienced a sharp phase of economic decline, and job supply was very low. This situation led to an increase in unemployment, a decrease in household budgets, the main concern of the population was to provide money for the necessities of daily life and the payment of utilities. Thus, the costs of maintenance and modernization of housing, not being considered a priority, have passed, in many 
cases, on a secondary level. As a result, many of the buildings in which the houses were located have deteriorated, others have been abandoned.

After 1990, the role of local government in making decisions about local community development increased. In the first years after the fall of communism, the steps are taken in Radauti by the local administration, although they were aimed at improving living conditions, accessibility of utilities, and diversification of urban services, however, involvement in housing restructuring can not be characterized as significant. Lack of financial means and coherent development strategies, limited experience in land management, political and economic instability, large numbers, and diversity of problems that needed to be solved are just some of the aspects that describe the context in which the city evolved in the early transition to democracy.

The restoration of the right to private property also had a great influence on the process of development and restructuring of the housing stock in the post-socialist period.

The transfer of the houses, through sale, from public property to private property and the restitution of the lands, greatly limited the possibility of the local administration to intervene in the management of the housing fund and to arrange the built urban space.

The revitalization of the economy contributed to the relaunch of the activity of the housing construction sector as a result of the adoption of the "demand-supply" principle, which boosted the entry of private entrepreneurs into the housing construction market, but also the voluntary involvement of the population in building their own homes.

The socio-economic transformations produced in the post-communist period and the deficiencies in the application of a set of urbanism norms favored and maintained the tendency of urban dispersion and heterogenization of the forms of housing. Thus, in the last three decades, residential areas have continuously expanded to the outskirts, to the detriment of agricultural land (in the south and north of the city, the built-up area has already expanded to the administrative territory of the settlement). In the last decade, we are witnessing a new trend of restructuring the residential space, that of capitalizing on free spaces in the built-up area (obtained by demolishing old buildings) for the construction of multi-story residential buildings.

\section{Analysis of the dynamics of the housing fund within the municipality of Rădăuți, after 1990}

In communist and post-communist Romania, the dynamics of the housing construction sector and its segments (private/public property, rural/urban housing, individual/collective, housing) reflects political, economic, and housing ideologies [16]. The process of restructuring the housing stock in Rădăuți was carried out both by rehabilitating and modernizing the existing housing stock, and by building new homes, either on the site of older buildings or vacant land inside or on the outskirts of the city.

Although dwelling is a fundamental need, over time, human needs related to housing have diversified by the elements of progress of society but especially with the particularities of human communities. If initially, the house was just a shelter, with the modernization of society, more and more attributes were assigned to it: space for relaxation, relationships, communication, space for recovery of work capacity, space for personal development, a place to retire from daily life, space with which the occupants are emotionally connected and which they arrange to respond as well as possible to their own needs and preferences. The current situation of the housing fund in Rădăuți is the result of continuous evolution and restructuring, produced in different political and socio-economic contexts. but also of the reflection, in housing practice, of the political decisions taken in different periods 
as well as of the housing preferences expressed by the population in recent decades, in particular. The research of the dynamics of the housing fund must take into account the fact that over $80 \%$ of the dwellings that make up the current housing fund of Rădăuţi municipality were built before 1990 .

The existing housing stock is modified annually, by including newly built homes, arrangements made to expand existing homes, change the destination of some spaces and transform them into homes and decommissioning others (demolition, change of destination). According to the statistical data provided by the National Institute of Statistics of Romania, through the Suceava County Directorate of Statistics, the housing fund of Rădăuți, in 1989, included 10,362 dwellings, and in 1990, 10,507 (another 145 dwellings were completed, most apartments under construction in the previous year, only 5 individual houses built from population funds) [17].

The dynamics of the housing fund at the level of Rădăuți municipality is represented in Figure 4.

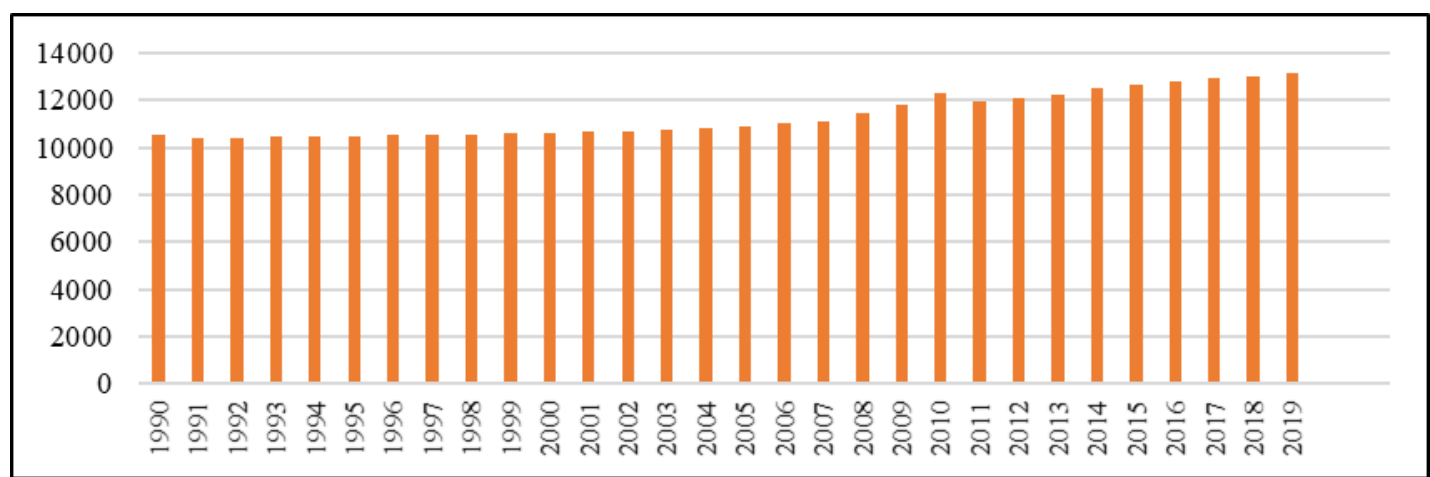

Figure 4. Evolution of the total number of existing dwellings in Rădăuţi municipality (1990-2019) (Source: authors' processing of INSSE TEMPO statistics, LOC101B)

Statistical data indicate that, during 1990-2019, the housing stock of Rădăuți was enriched with 2.654 homes, which represents $1 / 5$ of the existing housing fund, respectively $20.16 \%$. Overall, for the entire analyzed period, the average annual growth rate of the existing number of dwellings was $0.84 \%$, noting a slower period of growth until 2005 (the values recorded being very small, only $0.23 \%$ ) and an acceleration period after 2005, the average values reaching $1.39 \%$ (a doubling compared to the previous period). The analysis of statistical data highlights the fact that, in the first ten years after the fall of communism, the renewal of the housing stock was done at a very slow pace, being completed only 156 homes. Most of the houses were built in Rădăuți after 2000, as a consequence of the recovery of the economic situation of the city and the increase of the population's income. Thus, in the last two post-socialist decades the number of dwellings built $(2,560)$ exceeded the number of dwellings put into use in the last two decades of the socialist period $(2,314)$ when the pace of construction was particularly fast. If during the communist period the emphasis was on the construction of blocks of flats intended to house the labor force that served the new enterprises of the city, after $2000,90 \%$ of the houses built are represented by individual houses raised from the population funds.

During the analyzed period, the structure by forms of ownership of the housing stock of the city of Rădăuți changed by increasing the number of dwellings in majority private ownership from $88.5 \%$ (1993) to $97.5 \%$ (2019), simultaneously with the decrease of the number of dwellings in majority state ownership from $11.5 \%$ (1993) to only $2.5 \%$ (2019). 


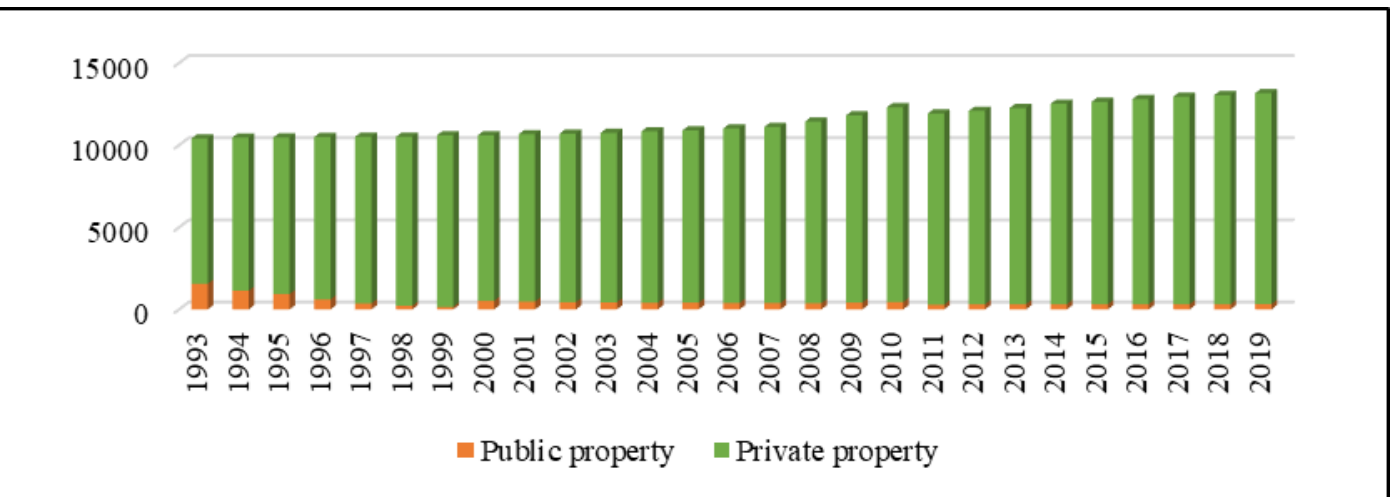

Figure 5. Rădăuți - Dynamics of the existing number of dwellings by the form of ownership (1993-2019) (Source: authors' processing of INSSE TEMPO statistics, LOC104B)

This was primarily due to the change in the legislation governing property and housing, and the transfer, by sale, of a significant number of dwellings (especially apartments) from state ownership to private ownership, starting in 1990.

Another indicator whose evolution provides benchmarks for characterizing the overall dynamics of the housing stock of Rădăuți is the number of completed homes during the year, its evolution is represented in Figure 6. During the analyzed period, we notice the fact that the annual rhythm of construction and completion of dwellings registers a rather fluctuating dynamic marked by decreasing, accelerating, stagnating, or slowing downtrends that follow one another quite quickly. Thus, in the first decade after 1990, marked by the restructuring of the industry and the decline of the construction sector, the growth rate remains slow, with slight fluctuations, now being recorded the minimum value of the period (4 homes completed in 1998). The interval 2000 - 2006 is characterized, for the first time after 1990, by a continuous increase of the number of dwellings completed annually, during this period also registering the maximum number of dwellings completed in a year, respectively 501, built-in 2010).

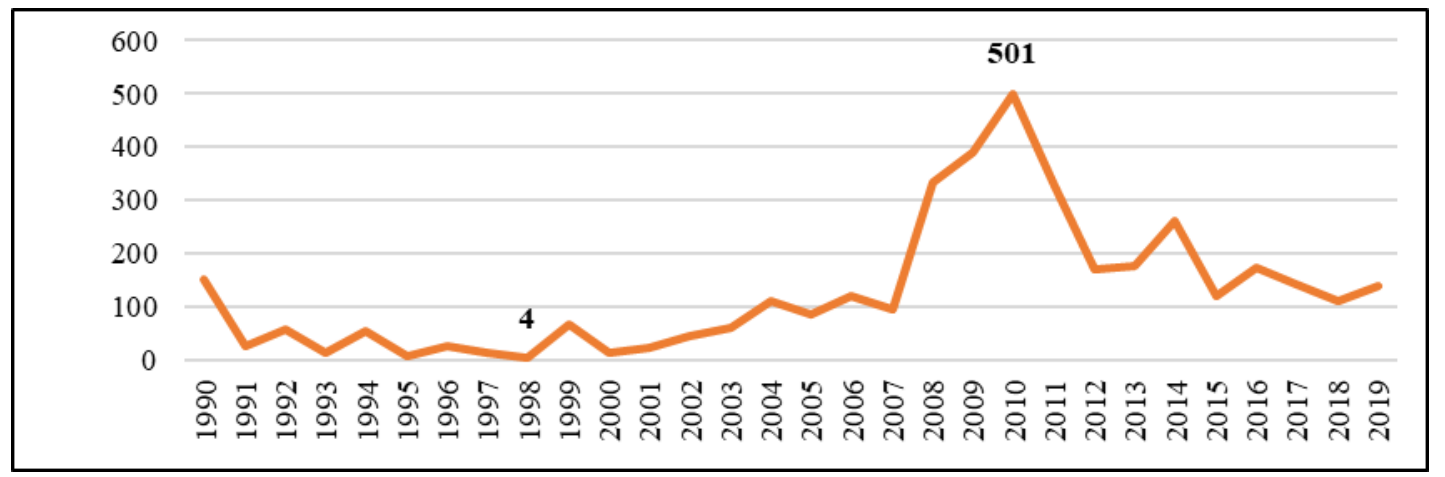

Figure 6. Rădăuți - Dynamics of the number of completed homes during the year (1993-2019) (Source: authors' processing of INSSE TEMPO statistics, LOC104B)

The dynamic is in a strong downward trend until 2012 when the number of completed dwellings barely reaches a third of the value recorded two years ago. Until 2019, the dynamics become fluctuating again and highlights recovery periods $(2014,2016)$ separated by periods of decline.

The situation of the financing sources used for the completion of housing constructions is represented in Figure 7. 


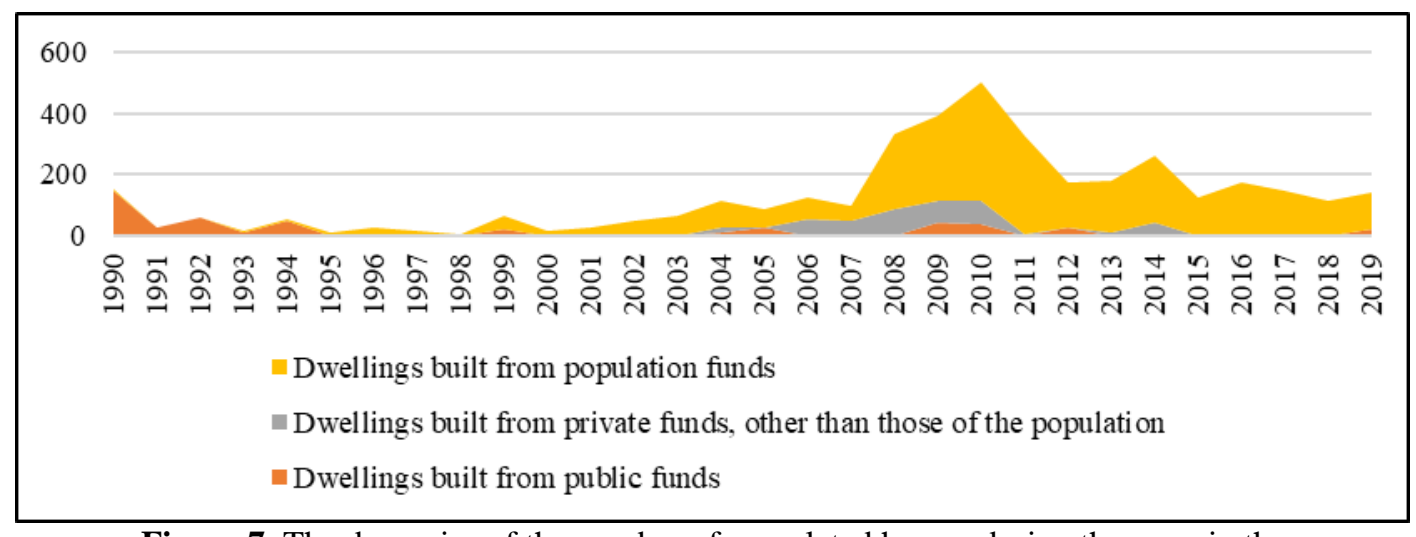

Figure 7. The dynamics of the number of completed homes during the year, in the municipality of Rădăuți, by funding sources (1993-2019)

(Source: authors' processing of INSSE TEMPO statistics, LOC104B)

At the level of Rădăuți, during the analyzed period, the living area doubled, 426,740 square meters were put into use after 1990, which represents $10.48 \%$ of the increase achieved in Suceava County.

Although the value of the average annual growth rate of the living space, calculated for the entire analyzed time interval, amounted to $4.15 \%$, at the level of shorter time intervals, the fluctuations were quite large. Thus, between 1990-2000, the value recorded for this indicator was $0.66 \%$, in the period $2001-2011,4.65 \%$ (the highest value) and after 2012 , the values decreased to $0.36 \%$ (lower values than in the first interval).

This reality can be correlated with the evolution of the economy in a national context, the restructuring of all sectors of the economy, the decline of industry and the housing construction sector after 1989, aspects that explain why Romanian cities were built very little in the first decade after the 1989 Revolution.

After 2003, the number of individual dwellings built by the population increased from its funds, this situation being the consequence of the improvement of the financial situation of the population (especially of people who emigrated to Western European countries), of the change of housing preferences under the influence of the Western model, but also of the privatization of the construction sector and the entry of the housing market by real estate developers.

After the crisis of 2008 and until 2010, housing construction is maintained, by inertia, on an upward trend as a result of the completion of housing whose construction had begun years before. The decline that followed after 2012 was largely influenced by the global financial crisis of 2008 and its aftermath: the bankruptcy of many companies, declining purchasing power of the population, rising construction prices, rising dwellings prices, more restrictive lending conditions, economic instability, etc.

The restructuring of the housing stock of Rădăuți municipality is reflected both by its quantitative dimension (dynamics of the main indicators of the housing fund, analyzed previously) and by its territorial dynamics highlighted in Figure 9.

From a quantitative point of view, we emphasize the fact that the housing fund underwent a significant process of renewal in the post-socialist period, 1/5 of the houses that make it up being built after the year 2000 .

The analysis, for the period 1982-2019, of the territorial dynamics of the built fund of Rădăuți municipality highlights a series of defining features. Thus, we notice that the city registered positive territorial dynamics, reflected by the expansion and densification of the built space. 


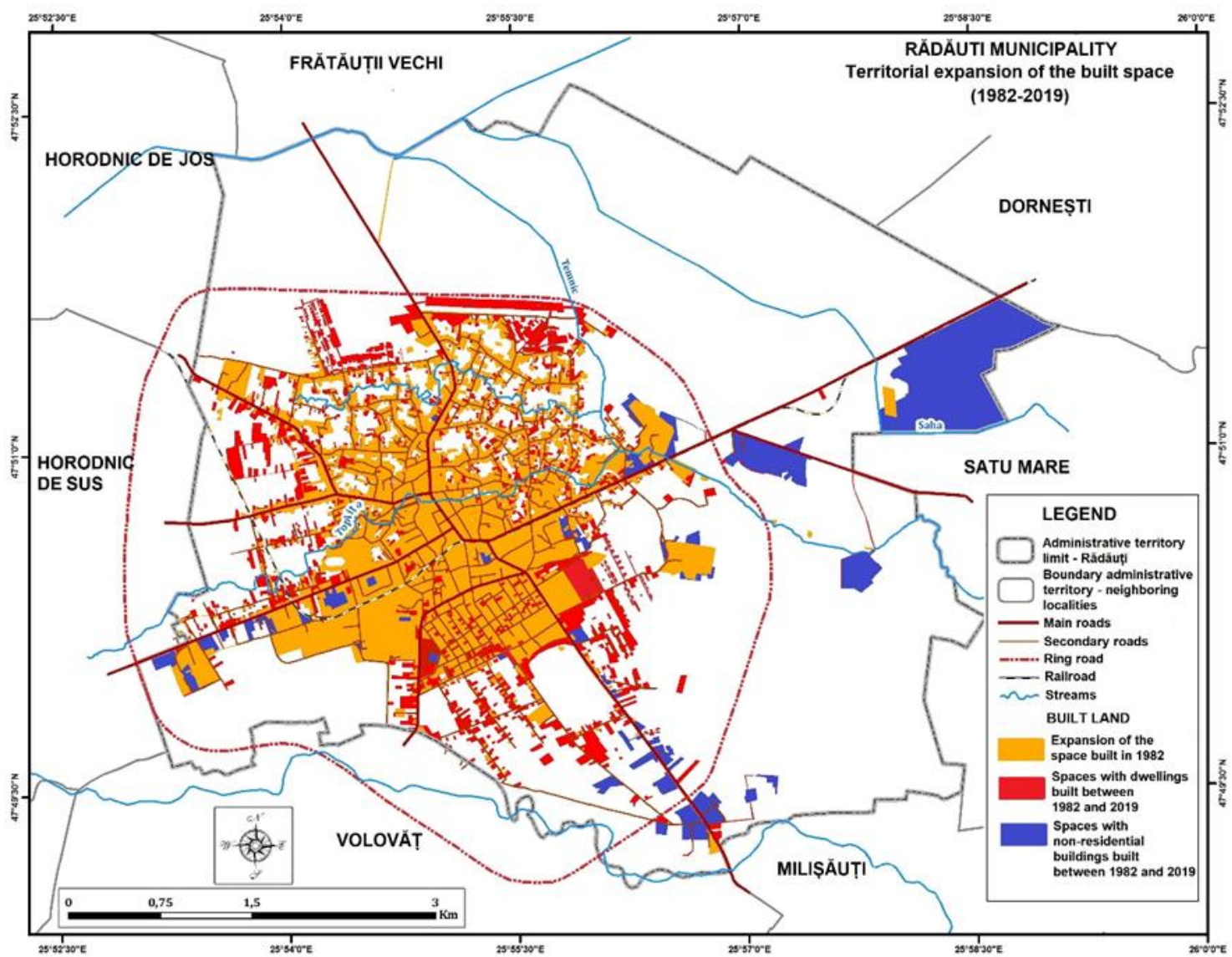

Figure 8. Restructuring of the built space of Rădăuți municipality between 1982 and 2019

An obvious reality, which can be deduced from the analysis of the map, is that the postcommunist territorial expansion was achieved based on the expansion of residential areas. The extension of the built spaces to the peripheries took place in the southern, northern and western, and south-eastern areas of the city, while the densification characterized, mainly the eastern and south-western areas. If in the southern part of the city the structure of the built space includes, in addition to residential buildings (majority) and nonresidential facilities, given the position along the road that connects Radauti to the county seat (the most important socio-economic axis of the city), in the northern and western area, the expansion was achieved exclusively through the development of residential spaces.

Another feature of the housing restructuring process is the increase in the height level of the built buildings and implicitly of the city profile. The old residential structures (represented by individual houses organized, usually on one level) have been replaced with new structures, represented by multi-level residential buildings (ground floor $+1-2$ floors in the case of individual houses and ground floor $+3-5$ floors in the case of collective buildings).

We also recall that the restructuring of the existing housing stock also had an important qualitative dimension. The intensification of the activity of building new houses in Rădăuți and the neighboring localities led to the appearance of a large number of warehouses and shops selling construction materials in the city, this fact is a premise for the redevelopment and modernization by the owners of the existing housing stock. Special attention was paid to the interior and exterior redevelopment, increasing the thermal 
efficiency of buildings, but also the repair and maintenance of buildings and their connection to utilities to increase the comfort of living.

The economic recovery of Rădăuți was based on the development of services. Most of the companies established in Rădăuți after 1990, were businesses that started from small capital and developed, over time, by their forces. In 2014, according to the data of the National Office of the Trade Register, 1056 economically active agents were registered at the level of the municipality, of which $90.76 \%$ are micro-enterprises (they have a maximum of 9 employees). The diversification of services in the post-socialist period has determined an increasing demand for spaces for company headquarters, offices, spaces for activities. Most owners preferred to rent spaces for companies to operate, which consequently led to a change in the functionality of many buildings in the last three decades, the loss of residential function being another aspect of the restructuring of the housing stock of Radauti.

\section{CONCLUSIONS}

The fall of the communist regime determined the change of the political and socioeconomic context in which Rădăuți evolved after 1990 and oriented the steps of the local administration and citizens towards finding efficient solutions to adapt the existing structures (human, economic, physical) to the new development context, to ensure the well-being of citizens, quality of life and housing.

The defining features of the housing stock were undoubtedly acquired during its historical evolution, but in its development and structuring with an important contribution, there were three stages: the period of the Habsburg occupation (late seventeenth century - the first part of the 19th century), the socialist period (mid-20th century - 1989) and the postsocialist period (after 1990). All these stages of development were reflected in the demographic, territorial, and functional development of the city and, implicitly, in the development of the housing stock and the incorporation in the residential areas of new structures organized according to the specific models of the respective periods.

The development and structuring of the housing stock were influenced by historical, political, economic, and demographic factors that acted in an integrated way, but with a different weight over time. Historical factors have had a major influence on the formation and structuring of the housing stock in Radauti, they coincide with the main events in the history of the settlement, each stage of territorial and functional evolution through contributing to the structuring of urban space and, implicitly, to the creation and development housing stock. Demographic factors play a key role in measuring the demand for housing and, in part, in meeting the need for existing housing at the local level by building, buying, or renting housing. Economic factors have been, in all periods, but especially after 1990, the support of the process of development and restructuring of the built fund. The revitalization of the economy contributed to the relaunch of the activity of the housing construction sector as a result of the adoption of the "demand-supply" principle, which boosted the entry of private entrepreneurs into the housing construction market, but also the voluntary involvement of the population in building their own homes. The quantitative dimension of the housing fund restructuring is reflected by the dynamics of the main indicators of the housing stock (an increase of the total number of dwellings by 2654 units; an increase of the share of private property over dwellings $97.5 \%$ in parallel with a decrease of the share of publicly owned dwellings to $2,5 \%$, doubling the existing living space in 2019 compared to the existing one in 1990). The qualitative dimension of the restructuring includes aspects related to the modernization of housing, 
new exterior design, efforts to improve the energy efficiency of buildings, and the connection to utilities.

The territorial dynamics of the built fund of Rădăuţi municipality highlights a series of defining features: positive territorial dynamics, reflected by the expansion and densification of the built space; the extension of the built spaces to the peripheries took place in the southern, northern, and western and south-eastern area of the city, while the densification characterized, mainly the eastern and south-western area; increasing the level of height of the buildings built and, implicitly, changing, in certain areas, the profile of the city; the diversification of the physiognomy of the residential areas as a result of the incorporation of some old and new structures; the increase of the heterogeneity of the built space and the models of the arrangement of the inhabited space.

In conclusion, we emphasize that the development of the housing stock of Radauti was a process associated with the overall development of the locality, which occurred under the interconnected influence of all categories of premises analyzed (historical, demographic, political, and economic) and the transition to democracy, decentralization, and adaptation to the market economy have been key factors in organizing and restructuring the housing stock in line with the needs of different periods.

\section{Acknowledgment:}

This work is supported by project POCU/380/6/13/125040, entitled "Development of the tertiary university education to support the economic growth - PROGRESSIO", cofinanced by the European Social Fund under the Human Capital Operational Program 2014-2020.

\section{REFERENCES}

[1] *** UN Habitat. Urbanization and Development: Emerging Futures, World Cities Report 2016, United Nation Settlements Programme. Nairobi, Kenya, 2016, pp. 49, available at www.unhabitat.org

[2] Vîrdol , D., Suditu,B., Liliana Dumitrache , Vâlceanu D.G, Dinamica fondului locativ în România între politică și politici, in Human Geographies - Journal of Studies and Research in Human Geography, București, Editura Universităţii, vol.9, no.2, pp. 218, 2015.

[3] Amann, W., Mundt, A. Designing a new rental housing law for Romania. International Journal of Law in The Built Environment. Vol. 2 No. 2, pp. 157-177, 2010, 10.1108/17561451011058799, available at www.researchgate.net.

[4] Sýkora, L., 2009. Post-socialist cities. In: Kitchin, R., Thrift, N. (Eds.), International Encyclopedia of Human Geography. Elsevier, Oxford, pp. 387-395.

[5] Matlovič, R. Transformačné procesy intraurbánnych štruktúr Prešova ako odraz celospoločenských zmien v ostatnom decéniu. In Matlovič, R., ed. Urbánny vývoj na rozhraní milénií. Urbánne a krajinné štúdie, 3. Prešov (Filozofická fakulta Prešovskej univerzity), pp. 27 38, 2000.

[6] Vîrdol , D., Suditu, B., Liliana Dumitrache, Vâlceanu D.G, Dinamica fondului locativ în România între politică și politici, in Human Geographies - Journal of Studies and Research in Human Geography, București, Editura Universității, vol.9, no.2, p. 218, 2015.

[7] Sýkora, L., 2015. Cities Under Postsocialism. In: James D. Wright (editor-in-chief), International Encyclopedia of the Social \& Behavioral Sciences, 2nd edition, Vol 3. Oxford: Elsevier. pp. 605-611.

[8] ***Strategia natională a locuirii 2016-2030, Proiect, pp. 4-5, available at www.mmediu.ro. 
[9] *** Strategia de dezvoltare teritorială a României studii de fundamentare, Synthesis report. 2014, pp. 4, available at www.sdtr.ro.

[10] ***National Institute of Statistics, Housing Fund. The year 2018, Romania, pp. 5, 2019.

[11] Luchian, D. Rădăuți - Romanian hearth of socialist traditions and achievements, Publishing House Litera, pp. 20, 1982.

[12] Luchian, D. Rădăuți - Romanian hearth of socialist traditions and achievements, Publishing House Litera, pp. 41, 1982.

[13] Ranci, C. Social Vulnerability in Europe. The New Configuration of Social Risks. Palgrave Macmillan. pp. 3-23, 2010.

[14] Cetindag, B., Morad, M., Parsa, A. Cities in transition: emerging urban regeneration and housing policies in Istanbul, with comparative analysis of Budapest, in Urban dynamics and housing change - Crossing into the 2nd Decade of the 3rd Millennium, 22nd International Housing Research Conference, Istanbul, Turkey, pp.2, 2010, available at http://usir.salford.ac.uk/

[15] Luchian, D. Rădăuți - Romanian hearth of socialist traditions and achievements, Publishing House Litera, pp. 15-16, 1982.

[16] Vîrdol , D., Suditu, B., Liliana Dumitrache , Vâlceanu D.G, Dinamica fondului locativ în România între politică și politici, in Human Geographies - Journal of Studies and Research in Human Geography, București, Editura Universității, vol.9, no.2, p. 208, 2015.

[17] ***Suceava County Directorate of Statistics, Rădăuţi locality file, 1985-1995 